\title{
Metode Pembelajaran Mind Map dan Bercerita dengan Gaya Kognitif, Pengaruhnya terhadap Kemampuan Membaca Permulaan
}

\author{
Putri Rahmatika ${ }^{1 凶}$, Sofia Hartati ${ }^{2}$, Elindra Yetti ${ }^{3}$ \\ Pendidikan Anak Usia Dini, Universitas Negeri Jakarta
}

\begin{abstract}
Abstrak
Penelitian ini bertujuan untuk mengetahui pengaruh antara metode pembelajaran mind map dan gaya kognitif independen dependen terhadap kemampuan membaca permulaan. Penelitian ini merupakan penelitiann kuantitatif, metode yang digunakan adalah metode eksperimen dengan menggunakan desain faktorial $2 \times 2$. Penelitian ini menggunakan randomisasi untuk menentukan subjek penelitian untuk kelompok eksperimen dan kelompok kontrol. Populasi penelitian adalah anak TK kelompok B. Data penelitian diperoleh dari hasil observasi yang dilakukan dengan menggunakan lembar instrumen, kemudian data yang diperoleh di analisis. Dalam pengujian hipotesis menggunakan analisis varian anava dua jalur. Hasil penelitian mengungkapkan bahwa metode pembelajaran dan gaya kognitif dapat mempengaruhi kemampuan membaca permulaan. Terdapat interaksi yang signifikan antara penerapan metode pembelajaran dan gaya kognitif dalam menentukan kemampuan membaca permulaan.
\end{abstract}

Kata Kunci: metode pembelajaran mind map; gaya kognitif; membaca permulaan

\begin{abstract}
Abstact
This study aims to determine the effect of mind map learning methods and independent dependent cognitive styles on initial reading skills. This research is a quantitative study, the method used is an experimental method using $2 \times 2$ factorial design. This study uses randomization to determine the research subjects for the experimental group and the control group. The study population was kindergarten children in group B. The research data were obtained from observations made using the instrument sheet, then the data obtained were analyzed. In testing hypotheses using two-way Anova variance analysis. The results of the study revealed that learning methods and cognitive styles can influence early reading skills. There is a significant interaction between the application of learning methods and cognitive style in determining initial reading skills.
\end{abstract}

Keywords: mind map learning methods; cognitive style; beginning reading

Copyright (c) 2019 Putri Rahmatika, Sofia Hartati.,Elindra Yetti

$\triangle$ Corresponding author :

Address : Jl Mawar, Bandar Lampung

ISSN 2356-1327 (Media Cetak)

Email : Putri.rahmatika29@yahoo.com

ISSN 2549-8959 (Media Online) 


\section{PENDAHULUAN}

Anak memperoleh bahasa awalnya dari orangtua lebih dikenal dengan bahasa ibu. Bagaimana orangtua memberikan pengasuhan untuk memberikan stimulus bahasa ke anak. Sebagaimana disampaikan oleh Elizabeth \& J. Steven dalam penelitiannya menyebutkan bahwa pentingnya pengasuhan anak dan hubungan yang baik antara anak dan lingkungan keluarga yang dapat merangsang pemerolahan bahasa(Pungello, Iruka, Dotterer, Mills-Koonce, \& Reznick, 2009). Salah satu kemampuan penting ketika memasuki pendidikan lanjut adalah kemampuan membaca permulaan selain menulis, berhitung dan karakter. Kemampuan membaca merupakan dasar untuk menguasai berbagai bidang studi (Kebudayaan, 2012). Jika anak pada pada usia memasuki pendidikan lanjut belum memiliki kemampuan membaca, maka ia akan mengalami kesulitan dalam mempelajari berbagai pembelajaran selanjutnya. Oleh karena itu, anak belajar membaca agar dapat membaca untuk belajar. Kemampuan membaca permulaan anak adalah kemampuan anak menguasai tehnik membaca dan memahami isi bacaan dengan baik. Untuk itu, agar dapat menstimulus penambahan kosakata anak diperlukan pendekatan dalam pembelajaran dalam pengembangan kemampuan membaca.

Sarah Mc Geown menyebutkan tentang "Implications For The Skills Predicting Early Reading Acquisition And Development" menjelaskan bahwa pendekatan pembelajaran yang dilakukan untuk mengembangkan kemampuan membaca memiliki pengaruh antara pendekatan pada kelas kontrol dan kelas eksperimen (Geown, 2015). Berdasarkan penelitian tersebut, maka dapat dijelaskan bahwa anak dapat belajar tentang mengolah kata, memposes dan melakukan pengulangan dengan melakukan strategi yang akan membuat anak menjadi aktif dalam kegiatan pembelajaran.

NAEYC "National Association for the Education of Young Children" menyebutkan bahwa buku cerita bukanlah satu-satunya media yang dapat digunakan untuk anak-anak dengan paparan bahasa tertulis. Anak-anak belajar membaca dari label, tanda-tanda dan jenis lain yang tercetak. Jadi penerapan metode pembelajaran mind map merupakan salah satu metode yang berisi konten gambar, simbol, warna, bentuk di dalamnya.

Wayan, Nyoman menyebutkan Media gambar merupakan salah satu media pembelajaran yang dapat membantu guru dalam proses pengajaran. Keterbatasan media akan mempengaruhi proses pembelajaran siswa dimana media yang sesuai akan mendukung proses pencapaian pembelajaran itu sendiri (., ., \& Nice Maylani Asril, 2014). Media gambar adalah media yang umum bisa dipakai, hal tersebut dikarenakan anak lebih tertarik dengan gambar dibandingkan dengan tulisan yang ada di papan.

Namun kenyataan dilapangan, Peneliti melakukan wawancara dan tes terhadap guru dan anak tentang pengajaran membaca permulaan kepada anak yang menghasilkan bahwa pada saat guru mengajak anak untuk mengenal huruf dan kata anak sibuk dengan dunia sendiri tidak mendengarkan guru, anak lebih senang membaca gambar daripada tulisan dibawah gambar, sehingga ada beberapa anak yang mengucapkan gambar tidak sesuai dengan tulisan yang ada dibawah gambar.

Masih terdapat pada anak usia 5-6 tahun yang belum mampu membaca rangkaian huruf dalam kata dan belum memahami makna kata dan kalimat sederhana yang dibaca, belum bisa membedakan huruf, menggabungkan huruf, 
terbaliknya penulisan huruf, terbaliknya penulisan kata dan penulisan huruf yang kurang pada suatu kata, akibatnya maksud dari tulisan anak sulit untuk dibaca atau dipahami. Guru memberikan media pembelajaran kurang menarik sehingga anak kurang tertarik untuk belajar membaca.

Pada tahun 2015 berdasarkan Hasil penelitian internasional, Programme for International Student Assessment (PISA) tentang kemampuan membaca siswa juga menyebutkan bahwa kemampuan membaca siswa di Indonesia menduduki urutan ke-69 dari 76 negara yang disurvei menunjukkan bahwa kemampuan membaca siswa Indonesia masih rendah dibandingkan negara lain, tetapi untuk matematika dan sains mengalami peningkatan, sementara dalam hal membaca masih kurang (OECD, 2016). Rendahnya kompetensi membaca siswa kita karena tidak dilatih untuk membaca. Membaca merupakan sebuah keterampilan, jadi harus dilatih secara terstruktur dan terus menerus. Oleh karena itu pemberian kemampuan hasil belajar membaca dimulai jauh sebelum anak berkembang atau sejak anak usia dini.

Pada tahun 2013 berdasarkan penelitian yang dilakukan, $88 \%$ anak usia 6-7 tahun sudah dapat mengenal huruf, namun 58\% masih mengalami kesulitan membaca kata, 47\% masih kesulitan membaca kalimat dengan lancar (Tjoe, 2013). Sehingga ketika di usia 5-6 tahun perlu mengenalkan membaca walaupun tidak dipaksa sesuai dengan kebutuhan anak.

Oleh karena itu, Peneliti ingin membuat kegiatan yang dilaksanakan dapat menumbuhkan minat baca peserta didik dan meningkatkan keterampilan membaca agar pengetahuan dapat dikuasai secara lebih baik. Materi baca yang disampaikan sesuai tahap perkembangan peserta didik. Saya ingin melihat efektifitas metode pembelajaran dalam meningkatkan kemampuan membaca anak, ingin juga melihat perbedaan metode pembelajaran membaca berdasarkan gaya kognitif.

Berdasarkan hal tersebut dibutuhkan pelaksanaan pembelajaran yang menggunakan metode yang tepat dalam melibatkan semua aspek kemampuan yang dimiliki anak. Salah satu metode yang dapat digunakan adalah metode pembelajaran mind map yang di didasari teori gabungan Piaget dan Vygotsky yang melibatkan inisiatif anak dalam melakukan berbagai macam aktifitas. Diharapkan dapat meningkatkan kemampuan dan kecerdasan anak karena pembelajaran dalam metode pembelajaran mind map melibatakn inisiatif guru dan dari dalam diri anak.

Vygotsky, juga menyatakan bahwa language plays a key role in children cognitive development (Santrock, 2008). Bahasa itu bisa memperbaiki kognitif anak karena melalui bahasa anak bisa berkomunikasi, dari komunikasi anak bisa mengontrol bagaimana komunikasi yang baik. Pada saat ditingkat lebih tinggi anak bisa mengungkapkan hasil pemikiran melalui verbal. Aktifitas membaca pasti mengalami suatu proses pembelajaran setiap individu. Belajar membaca tidak hanya melibatkan stimulus dan respon melainkan ada proses kemampuan kognitif dalam berfikir, untuk itu dibutuhkan suatu kemampuan kognitif pada masing-masing anak. Kemampuan kognitif pada masingmasing anak lebih bersifat stabil dan menetap. Kemampuan kognitif merupakan aspek yang dibutuhkan bagi anak dalam memperoleh, menyimpan, bahkan menerapkan suatu pengetahuan. Untuk itu, pembelajaran bagi anak harus diekmas dalam suasana bermain edukatif, menyenangkan, menumbuhkan rasa inisiatif anak yang bisa diaplikasikan melalui penerapan metode pembelajaran mind mapping. 
Dari uraian tersebut, bahwasanya anak akan bisa melakukan proses membaca permulaan ketika anak bisa mengekspresikan semua kemampuan kognitif yang anak miliki dengan sangat baik. Dengan suatu metode pembelajaran mind map, yang disesuaikan dengan kemampuan kognitif yang dimiliki masingmasing anak, anak dapat mengembangkan kemampuan bepikir kreatif. Metode pembelajaran mind map dalam membaca permulaan didesain sesuai dengan kebutuhan anak akan mengenal kata-kata dan makna.

Untuk itu peneliti bermaksud melakukan penelitian mengenai pengaruh penerapan metode pembelajaran dan gaya kognitif terhadap kemampuan membaca permulaan anak yang dilakukan di TK Kecamatan Kedaton, Bandar Lampung.

\section{METODOLOGI}

Penelitian ini melibatkan dua sekolah di kecamatan Kedaton yaitu TK Padma Mandiri sebagai kelas eksperimen dan sekolah TK Tunas Melati sebagai kelas kontrol. Metode yang akan digunakan pada penelitian ini adalah eksperimen. Metode eksperimen merupakan cara untuk melihat pengaruh yang terjadi pada variabel terikat setelah diberikan perlakuan pada kelompok eksperimen dan membandingkannya dengan satu atau lebih perlakuan pada kelompok kontrol yang serupa tetapi berbeda dalam hal perlakuan. Pada penelitian ini, dilakukan randomisasi untuk menentukan subjek penelitian yang akan masuk ke dalam kelompok eksperimen dan kelompok kontrol (Handini, 2012).

Metode penelitian ini menggunakan beberapa variabel penelitian diantaranya variabel perlakuan atau variabe independent yaitu metode pembelajaran mind map. Adapun variabel perlakuannya terdiri dari metode pembelajaran mind map $\left(\mathrm{A}_{1}\right)$ dan metode pembelajaran bercerita $\left(\mathrm{A}_{2}\right)$. Selanjutnya variabel moderator atau atribut yaitu gaya kognitif yang dibagi menjadi dua yaitu kognitif field independent $\left(\mathrm{B}_{1}\right)$ dan kognitif field dependent $\left(\mathrm{B}_{2}\right)$. Variabel terakhir yaitu variabel terikat atau variabet dependent yaitu kemampuan membaca permulaan anak.

Penelitian ini menggunakan desain penelitian eksperimen dengan rancangan disain factorial $2 \times 2$. Desain ini sangat tepat bagi eksperimentasi dibidang pendidikan mengingat penelitian ini untuk mengetahui tingka kemampuan (aptitude test) dalam mengungkap kemampuan dasar atau bakat khusus anak (Djaali \& Muljono, 2008). Selain itu juga variabel moderator atau atribut mengenai kemampuan kognitif sangat perlu dilakukan suatu proses perbandingan untuk mengetahui perlakuan apa yang paling efektif terhadap masing-masing main efek antara kognitig field independent $\left(\mathrm{B}_{1}\right)$ dan kogntif field dependent $\left(\mathrm{B}_{2}\right)$ yang mempengaruhi keterampilan membaca permulaan anak.

Berikut ini adalah rancangan eksperimen disan factorial 2 x 2 yang akan digunakan dalam penelitian ini :

Tabel Disain Factorial 2x2

\begin{tabular}{|c|c|c|}
\hline $\begin{array}{l}\text { Variabel } \\
\text { Perlakuan }\end{array}$ & $\begin{array}{l}\text { Metode } \\
\text { Pembelajaran }\end{array}$ & $\begin{array}{l}\text { Metode } \\
\text { Pembelajaran }\end{array}$ \\
\hline $\begin{array}{l}\text { (A) } \\
\text { Variabel } \\
\text { Atribut (B) }\end{array}$ & $\begin{array}{l}\text { Mind } \quad \text { Map } \\
\left(\mathrm{A}_{1}\right)\end{array}$ & Bercerita $\left(\mathbf{A}_{2}\right)$ \\
\hline $\begin{array}{l}\text { Kognitif Field } \\
\text { Independent } \\
\left(\mathrm{B}_{1}\right)\end{array}$ & $\mathrm{A}_{1} \mathrm{~B}_{1}$ & $\mathrm{~A}_{2} \mathrm{~B}_{1}$ \\
\hline $\begin{array}{l}\text { Kognitif Field } \\
\text { Dependent } \\
\left(\mathrm{B}_{2}\right)\end{array}$ & $\mathrm{A}_{1} \mathrm{~B}_{2}$ & $\mathrm{~A}_{2} \mathrm{~B}_{2}$ \\
\hline
\end{tabular}

Sampel adalah seluruh anak yang terdaftar pada kelompok B di TK Padma Mandiri dan TK Tunas Melati Kota Bandar Lampung tahun pelajaran 2017-2018. Dengan jumlah 50 anak dari kedua sekolah tersebut.

Sehingga disini peneliti bisa mengelompokkan dua klasifikasi gaya 
kognitif yaitu kognitif field independent (skor tinggi) dan kognitif field dependent (skor rendah). Melalui hasil pre-test juga diketahui seberapa besar kesamaan pada tingkat kemampuan membaca yang memiliki kemampuan relatif sama, antara sampel penelitian pada metode pembelajaran mind map dan metode pembelajaran bercerita.

Rancangan perlakuan yang akan diberikan terdiri dari metode pembelajaran mind map, metode pembelajaran Bercerita dengan gambar, susunan rancangan kegiatan perlakuan, dan tahapan-tahapan perlakuan yang akan diuraikan sebagai berikut.

Pada penelitian ini, perlakuan akan dilaksanakan sebanyak $8 \mathrm{x}$ pertemuan. Proses perlakuan dilaksanakan sesuai dengan rencana pelaksanaan pembelajaran yang telah disusun sebelumnya.

Prosedur pelaksanaan perlakuan terbagi dalam tiga tahap ; tahap persiapan mneyusun rencana pelaksanaan pembelajaran untuk dua kelompok kelas yaitu kelas eksperimen mind map dan kelas kontrol bercerita, kemudian dilakukan penyusunan instrumen. Selain menyusun instrumen dari keduanya, gaya kognitif juga merupakan variabel dalam penelitian ini. Tahap Pelaksanaan, melakukan post-test kemampuan membaca permulaan pada kelompok eksperimen dan kelompok kontrol. Kemudian diberikan assesmen gaya kognitif. Tahap akhir perlakuan, dilakukan post-test pada setiap kelompok eksperimen dan kontrol.

Tehnik Pengumpulan data pada penelitian peneliti membuat kisi-kisi instrumen, instrumen tersebut digunakan untuk observasi dengan menggunakan lembar assesmen. Kemudian data yang diperoleh dianalisis.

Analisis data terdiri dari analisis deskriptif dan analisis inferensial. Sebelum uji hipotesis perlu dilakukan uji persyaratan analisis data berupa uji normalitas dan homogenitas yang akan digunakan.

\section{HASIL DAN PEMBAHASAN}

Pengujan hipotesis menggunakan teknik analisis varians dua jalur (ANAVA) desain treatmen by level $2 \times 2$. Anava dua jalur (twoway anova) bertujuan mengetahui:

Pengaruh utama (Main Effect) yaitu mencari pengaruh Metode pembelajaran terhadap Kemampuan Membaca atau apakah terdapat perbedaan skor Kemampuan Membaca Siswa pada kelompok yang diajar dengan Metode pembelajaran yang berbeda dan mencari pengaruh Gaya Kognitif terhadap Kemampuan Membaca atau apakah terdapat perbedaan skor Kemampuan Membaca Siswa pada kelompok siswa dengan gaya kognitif yang berbeda, Metode pembelajaran yang digunakan dalam penelitian ini adalah Metode pembelajaran Mind Mapping $\left(\mathrm{A}_{1}\right)$ dan Metode pembelajaran Bercerita $\left(\mathrm{A}_{2}\right)$, untuk mengetahui signikan atau tidaknya perbedaan yang ada dilakukan dengan uji F, dengan kriteria pengujian Fhitung $>$ F Tabel, maka dapat disimpulkan perbedaan Kemampuan Membaca antara kelompok A1 da Kelompok A2 adalah signifikan, dan gaya Koginit yang digunakan dalam penelitian ini adalah Gaya Kognitif Independent $\left(\mathrm{B}_{1}\right)$ dan Gaya Kogniitif Dependent $\left(\mathrm{B}_{2}\right)$, untuk mengetahui signikan atau tidaknya perbedaan yang ada dilakukan dengan uji $\mathrm{F}$, dengan kriteria pengujian Fhitung > F Tabel, maka dapat disimpulkan perbedaan Kemampuan Membaca antara kelompok B1 da Kelompok B2 adalah signifikan.

Pengaruh interaksi (Interaction effect) yaitu mencari perbedaan Skor Kemampuan Membaca pada siswa yang belajar dengan Metode pembelajaran yang 
bereda (Mind Mapping dan Bercerita) dan memilki perbedaan dalam Gaya Kognitif (Independent dan Dependent), untuk mengetahui signikan atau tidaknya pengaruh interaksi yang ada dilakukan dengan uji $\mathrm{F}$, dengan kriteria pengujian Fhitung > F Tabel.

Pengaruh Sederhana (Simple Effect) yaitu mencari pengaruh Metode pemebelajaran yang digunakan pada kelompok Kelompok dengan Gaya Kognitif yang sama.

Simple effect 1): Mengetahui perbedaan rata-rata Kemampuan Membaca antara yang menggunakan Metode pembelajaran Mind Mapping dan Metode Pembelajaran Bercerita pada kelompok siswa dengan Gaya Kognitif Independent. Untuk mengetahui signikan atau tidaknya perbedaan yang ada pada kelompok (A1B1 $x$ A2B1) dilakukan dengan uji Tuckey, dengan kriteria pengujian p-Value (Sig) < alpha (0,05), maka dapat disimpulkan perbedaan Kemampuan Membaca antara kelompok (A1B1 x A2B1) adalah signifikan.

Simple effect 2): Mengetahui perbedaan rata-rata Kemampuan Membaca antara yang menggunakan Metode pembelajaran Mind Mapping dan Metode Pembelajaran Bercerita pada kelompok siswa dengan Gaya Kognitif Dependent. Untuk mengetahui signikan atau tidaknya perbedaan yang ada pada kelompok (A1B1 $\mathrm{x}$ A2B1) dilakukan dengan uji Tuckey, dengan kriteria pengujian p-Value (Sig) < alpha (0,05), maka dapat disimpulkan perbedaan Kemampuan Membaca antara kelompok (A1B1 X A2B1) adalah signifikan.

Rangkuman hasil perhitungan analisis varians dua jalur disajikan pada tabel berikut.
Tabel Rata-Rata Kemampuan Membaca pada Setiap Kelompok Perlakuan

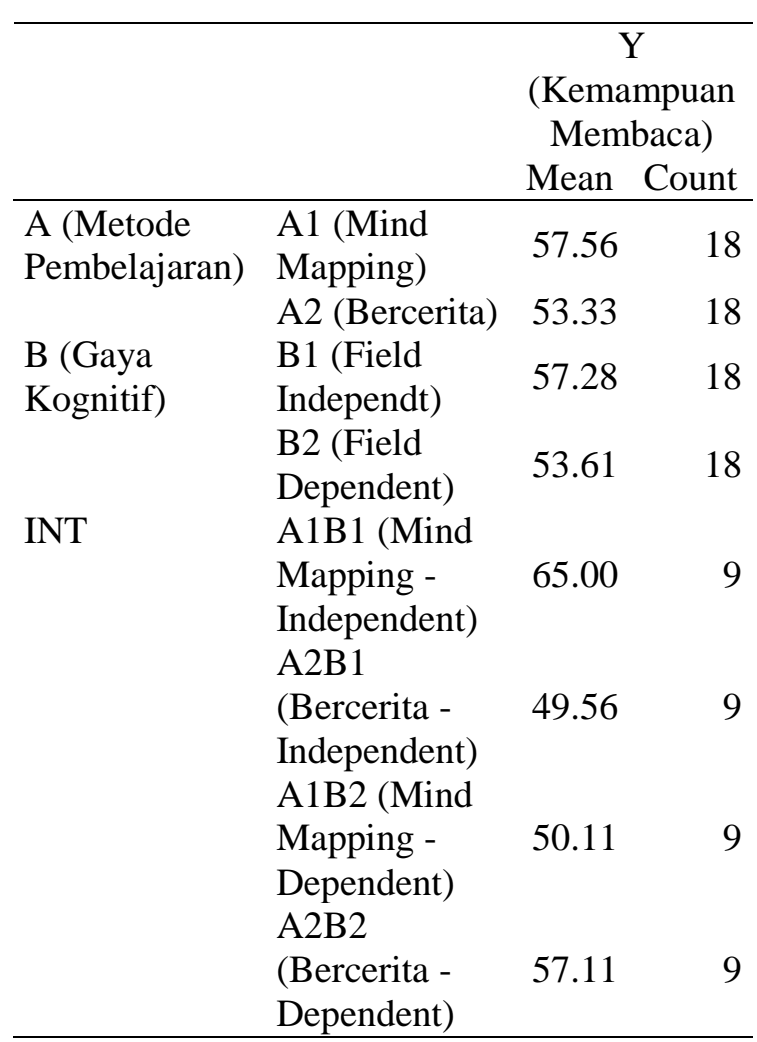

Tabel Rangkuman Hasil Perhitungan

Analisis Varians (ANAVA) Dua Jalur Tests of Between-Subjects Effects

Dependent Variable: Y (Kemampuan Membaca)

\begin{tabular}{|c|c|c|c|c|c|}
\hline Source & $\begin{array}{l}\text { Type III } \\
\text { Sum of } \\
\text { Squares }\end{array}$ & df & $\begin{array}{c}\text { Mean } \\
\text { Square }\end{array}$ & $\mathrm{F}$ & Sig. \\
\hline $\begin{array}{l}\text { Corrected } \\
\text { Model }\end{array}$ & $1414.889^{\mathrm{a}}$ & 3 & 471.630 & 40.139 & .000 \\
\hline Intercept & 110667.111 & 1 & 110667.111 & 9418.478 & .000 \\
\hline A & 160.444 & 1 & 160.444 & 13.655 & .001 \\
\hline B & 121.000 & 1 & 121.000 & 10.298 & .003 \\
\hline $\mathrm{A} * \mathrm{~B}$ & 1133.444 & 1 & 1133.444 & 96.463 & .000 \\
\hline Error & 376.000 & 32 & 11.750 & & \\
\hline Total & 112458.000 & 36 & & & \\
\hline $\begin{array}{l}\text { Corrected } \\
\text { Total }\end{array}$ & 1790.889 & 35 & & & \\
\hline
\end{tabular}

a. R Squared $=.790$ (Adjusted R Squared $=.770)$

Berdasarkan hasil analisis data yang telah dilakukan uji hipoteseis, terdapat beberapa temuan yang akan dibahas diantaranya adalah : 
Kemampuan membaca permulaan pada metode pembelajaran Mind map lebih tinggi daripada nilai kemampuan mmebaca permulaan yang diberikan metode pembelajaran bercerita.

Berdasarkan hasil pengolahan data dan perhitungan yang telah dijelaskan sebelumnya maka diperoleh beberapa perbedaan yang signifikan antara kemampuan membaca permulaan yag diberikan metode pembelajaran mind map dibandingkan dengan kemampuan membaca permulaan yang diberikan metode pembelajaran bercerita. Sehingga diperoleh suatu hasil kemampuan membaca permulaan yang diberikan metode mind map lebih tinggi daripada metode pembelajaran bercerita.

Senada dengan (Abad \& Usia, 2014), Pada pembuatan picture map ketika anak menuangkan ide tentang prediksi mereka tentang kelanjutan cerita, anak-anak mampu mengkomunikasikan dalam visualisasi gambar dan mengekspresikan secara verbal. Hal ini menunjukkan bahwa gambar merupakan alternatif media komunikasi yang digunakan untuk mengeskpresikan apa yang mereka pikirkan.

Berdasarkan perbedaan tersebut bahwa metode pembelajaran mind map merupakan metode yang menggunakan kegiatan pembelajaran aktif. Kegiatan tersebut menstimulus anak sehingga anak akan terbiasa menghasilkan ide-ide dan terlatih memecahkan masalah, membantu dalam mengingat, berkonsentrasi, media bermain, membuat pembelajaran menjadi menarik dan mudah dimengerti, senang dalam menuangkan imajinasi yang memunculkan kreativitas (Olivia, 2008).

Sedangkan metode Bercerita merupakan proses penyampaian materi pelajaran yang dilakukan secara verbal dari guru kepada anak. Dimana penyediaan materi pelajaran lebih didominasi guru sehingga guru masih banyak berperan aktif. Sehingga tugas anak lebih dominan sebagai pemerhati, penerima, dan mengerjakan tugas sesuai dengan instruksi yang diberikan oleh guru.

\section{Kemampuan membaca permulaan yang memiliki gaya kognitif field independent akan lebih tinggi daripada nilai kemampuan membaca permulaan yang memiliki gaya kognitif field dependent.}

Berdasarkan hasil pengolahan data dan perhitungan yang telah dideskripsikan sebelumnya maka diperoleh beberapa perbedaan yang signfikan antara kemampuan membaca permulaan yang memiliki gaya kognitif field independent dibandingkan dengan kemampuan membaca permulaan yang memiliki gaya kognitif field dependent.

Menurut Eva yang perlu dipertimbangkan ketika menempatkan gaya kognitif dengan individu lain adalah hubungan antara gaya kognitif dan pengaruhnya mencakup emosi, dan tingkah laku. Kemudian tidak ada model yang mengintegrasikan kedua gaya kognitif dan proses non kognitif dalam emosi, pemecahan masalah dan pengambilan keputusan (Cools, 2009). Sehingga dalam membaca gaya kognitif independent lebih baik jika diberi kebebasan dalam mengeksplor kegiatan dan independent tidak mudah dipengaruh oleh orang lain dalam memecahkan masalah, sedangkan gaya kognitif dependen lebih baik diarahkan dalam melakukan kegiatan kemudian orang lain bisa mempengaruhi emosi atau sikap dalam memecahkan masalah.

Berdasarkan perbedaan ini dapat dijelaskan gaya kognitif field independent lebih cenderung memandang proses informasi secara mandiri dalam menganalisis (Woolfolk, 2006). Bagi anak 
yang memiliki gaya kognitif field independent mempunyai sifat yang cenderung dimotivasi dari dalam dirinya sendiri dan kurang terpengaruh oleh kelompok dari luar, cenderung menyukai persaingan, memilih aktivitas dan bekerja secara terstruktur.

Berdasarkan hal tersebut anak akan melakukan pengulangan dalam mengekespresikan pola pikir dalam bentuk gambar, tulisan, maupun kata-kata. Berdasarkan hal tersebut yang memberikan pengaruh yang tinggi dalam meningkatkan kemampuan membaca permulaan anak adalah yang memiliki gaya kognitif field independent.

Anak yang memiliki gaya field dependent tertarik pada pesan verbal yang ada dalam masyarakat, lebih besar memperhitungkan kondisi sosial sebagai feeling dan bersikap tetapi untuk meningkatkan kemampuan membaca permulaan memiliki ketergantungan dan motivasi eksternal untuk sering dapat melakukan kegiatan membaca.

Berdasarkan dari hasil yang diperoleh, dapat disimpulkan kemampuan membaca permulaan anak yang memiliki gaya kognitif field independent lebih tinggi daripada anak yang memiliki gaya kognitif field dependent.

\section{Terdapat pengaruh interaksi antara metode pembelajaran dan gaya kognitif terhadap kemampuan membaca permulaan}

Berdasarkan dari hasil pengolahan didapat adanya pengaruh interaksi antara metode pembelajaran dan gaya kognitif terhadap kemampuan membaca permulaan. Hal ini diperkuat oleh teori bahwa untuk mengembangkan kemampuan bahasa anak yang mencakup berbicara, mendengar, membaca, dan menulis harus memberi kesempatan kepada anak untuk memperoleh pengalaman sebanyak-banyaknya yang disesuaikan dengan kemampuan perkembangan dan kebutuhan anak (Moeslichtoen, 2004). Sehingga terjadi pengaruh interaksi antara penerapan metode pembelajaran yang timbul dari dalam diri anak dan motivasi anak itu sendiri dan gaya kognitif yang faktornya diperoleh dari lingkungan, guru yang saling mempengaruhi dalam meningkatkan kemampuan membaca permulaan anak.

Senada dengan itu, ditemukan bukti bahwa melalui pembuatan picture map dalam kegiatan storytelling, siswa difasilitasi untuk mewujudkan hal-hal tersebut saat mengembangkan cerita. Mereka juga terlihat bertukar pikiran atau ide cerita, sehingga beberapa anak terlihat mengubah isi cerita dengan menambahkan gambar baru sesuai saran temannya (Abad \& Usia, 2014).

Sehingga, anak-anak yang duduk berdekatan turut menyimak cerita yang disampaikan saat menjelaskan picture map. Beberapa dari mereka menyimak dengan cermat dan saling memberikan pendapat dan ide baru terhadap isi cerita. Hal ini menunjukkan mereka mampu bekerja dan berpikir secara dinamis dan fleksibel. Sehingga adanya pengaruh antara metode pembelajaran dan gaya kognitif karena dapat memberikan kontribusi terhadap peningkatan kemampuan membaca.

Hasil penelitian didapatkan kelompok anak yang memiliki gaya kognitif field independent akan optimal kemampuan membaca permulaannya jika diberikan perlakuan metode pembelajaran mind map. Sebaliknya dengan anak yang memiliki gaya kognitif field dependent kan lebih tinggi jika diberikan metode pembelajaran bercerita.

Berdasarkan dari hasil yang diperoleh dapat disimpulkan bahwa terdapat interaksi antara metode pembelajaran dan gaya 
kognitif terhadap kemampuan membaca permulaan anak.

Kemampuan membaca permulaan yang diberikan metode pembelajaran Mind map yang memiliki gaya kognitif field independent akan lebih tinggi daripada nilai kemampuan membaca permulaan yang diberikan metode pembelajaran bercerita yang memiliki gaya kognitif field independent.

Berdasarkan hasil pengolahan data, terdapat perbedaan kemampuan membaca permulaan yang diberikan metode pembelajaran bercerita yang memiliki gaya kognitif field independent. Hasil yang didapatkan menunjukkan bahwa penguasaan kemampuan membaca permulaan yang diberikan metode pembelajaran mind map yang memiliki gaya kognitif field independent lebih tinggi daripada anak yang diberikan metode pembelajaran bercerita yang memiliki gaya kognitif field independent.

Keberhasilan pada kelompok yang diberikan metode pembelajaran mind map yang memiliki gaya kognitif field independent dikarenakan pada metode ini dipengaruhi rasa inisiatif dari dalam diri anak (Roopnarine \& E, 2011). Metode yang dapat menarik anak untuk mempelajari sesuatu hal dengan baik dan memberikan contoh yang bermakna kepada anak sehingga kemampuan instrinsik yang ada dalam diri anak dapat dikembangkan dengan baik.

Guru perlu adanya pemahaman terhadap gaya kognitif dalam setiap pembelajaran, bahwa sistem memproses informasi secara visual dan memproses secara verbal memiliki keterbatasan untuk memproses, untuk melakukan pembelajaran aktif diperlukan serangkaian proses kognitif yang terkoordinasi dalam pembelajaran. Sehingga pembelajaran mind map dengan kognitif independent lebih tinggi dibandingkan bercerita karena siswa melibatkan diri ke dalam proses pembelajaran, pembelajaran menjadi bermakna, mampu mengembangkan konsep sendiri, memiliki gambar, memilih kata, mengatur gambar, dan memadukan verbal dan visual dengan pengetahuan yang dimiliki sebelumnya.

Berdasarkan hasil yang diperoleh dapat disimpulkan bahwa kemampuan membaca permulaan yang diberikan metode pembelajaran mind map terhadap anak yang memiliki gaya kognitif field independent lebih tinggi dari diberikan metode pembelajaran bercerita yang memiliki gaya kognitif field independent.

Kemampuan menulis permulaan yang diberikan metode pembelajaran mind map yang memiliki gaya kognitif field dependent akan lebih rendah daripada nilai kemampuan membaca permulaan yang diberikan metode pembelajaran bercerita yang memiliki gaya field dependent.

Berdasarkan hasil pengolahan terdapat perbedaan kemampuan membaca permulaan yang diberikan metode pembelajaran mind map yang memiliki gaya kognitif field dependent dengan anak diberikan metode pembelajaran bercerita yang memiliki gaya kognitif field dependent. Hasil yang didapat menunjukkan bahwa penguasaan kemampuan membaca permulaan yang diberikan metode pembelajaran mind map yang memiliki gaya kognitif field dependent lebih rendah daripada anak yang diberikan metode pembelajaran bercerita yang memiliki gaya kognitif field dependent.

Menurut Isbell, Dimasukkannya mendongeng akan membantu anak-anak dalam memperluas cerita pemahaman, menceritakan kembali secara lisan, dan mengenali elemen cerita. Menggabungkan 
pendekatan-pendekatan ini dapat memberikan pengalaman literatur yang kuat untuk mempengaruhi perkembangan dan cerita bahasa lisan pemahaman anak-anak faktor penting dalam pengembangan literasi mereka (Isbell et al., 2004).

Dengan begitu, Yasa, dkk menjelaskan bahwa anak yang memiliki gaya kognitif field dependent cenderung memilih belajar dalam kelompok dan sesering mungkin berinteraksi dengan guru, memerlukan ganjaran/penguatan yang bersifat ekstrinsik. Untuk anak dengan gaya kognitif field dependent ini guru perlu merancang apa yang harus dilakukan dan bagaimana melakukannya (Yasa \& Dkk, 2013).

Oleh karena itu, anak dengan pembelajaran bercerita dengan gaya field dependent jadi sering berinteraksi dengan guru, memperoleh intruksi untuk memecahkan masalah, mendapatkan penguatan atau motivasi dari orang lain pada saat melakukan proses kegiatan pembelajaran. Anak lebih bisa menerima informasi dari cerita yang didengarkan. Sehingga anak dapat mengembangkan literasi mereka.

Keberhasilan pada kelompok yang diberikan metode pembelajaran bercerita yan memiliki gaya kognitif field dependent lebih tinggi dibandingkan dengan metode pembelajaran mind map hal ini karena metode pembelajaran bercerita dalam membaca lebih fokus pada kemampuan dari guru di kelas. Sehingga menjadi anak yang memiliki gaya kogntif field dependent dapat mengembangkan kemampuan awal dari dalam diri anak.

Hal ini dijelaskan dalam teori Smith bahwa seseorang yang memiliki gaya kognitif field dependent dikategorikan sebagai individu yang kemungkinan besar belajar secara lebih efektif di bawah kondisi sosial kemudian barulah dipengaruhi oleh kepribadian (Smith, 2009). Sehingga keberhasilan bercerita cocok dan mendukung proses perkembangan belajar yang baik untuk anak yang memiliki gaya kognitif field dependent.

Berdasarkan hasil yang diperoleh, dapat disimpulkan bahwasanya kemampuan membaca permulaan yang diberikan metode pembelajaran mind map terhadap anak yang memiliki gaya kognitif field dependent lebih rendah dari diberikan metode pembelajaran bercerita terhadap anak yang memiliki gaya kognitif field dependent.

Nilai kemampuan membaca permulaan yang diberikan metode pembelajaran mind map yang memiliki gaya kognitif field independent akan lebih tinggi daripada nilai kemampuan membaca permulaan yang diberikan metode pembelajaran mind map yang memiliki gaya kognitif field dependent

Berdasarkan hasil pengolahan data terdapat perbedaan kemampuan membaca permulaan yang diberikan metode pembelajaran mind map yang memiliki gaya kognitif field independent dengan anak diberikan metode pembelajaran mind map yang memiliki gaya kognitif field dependent. Hasil yang diperoleh menunjukkan bahwa kemampuan membaca permulaan yang diberikan metode pembelajaran mind map yang memiliki gaya kognitif field independent lebih tinggi daripada anak yang diberikan metode pembelajaran mind map yang memiliki gaya kognitif field dependent.

Keberhasilan yang diperoleh metode pembelajaran mind map yang memilki gaya kognitif field independent karena pada metode ini kemampuan membaca dipengaruhi aktivitas intrinsik yang efektif di bawah kondisi pola pikir dari dalam diri anak dan motivasi belajar yang terdapat dari diri anak. Sehingga cocok dengan pelaksanaan pembelajaran metode mind map karena mengatur diri anak untuk dapat 
mengambil inisiatif untuk belajar membaca permulaan.

Berdasarkan teori bahwa pelaksanaan suatu metode yang melibatkan demonstrasi yang bermakna akan dapat mengembangkan pemahaman kongkrit anak, dapat mengkomunikasikan kemampuan kognitif anak, mengembangkan kemampuan mengamati secara teliti dan cermat, dapat mengarahkan perilaku teliti, dan peniruan atau pengenalan secara tepat terhadap pengetahuan yang diberikan (Moeslichtoen, 2004).

Oleh karena itu, metode mind map yang memiliki field independent lebih tinggi dari field dependent karena melibatkan keaktifan anak sehingga membuat anak menemukan informasi secara mandiri, dapat mengolah informasi yang ditemukan, dapat mengerjakan tugas tanpa bimbingan, mampu mengembangkan konsep yang terstruktur, memiliki ke hatihatian dalam mengerjakan sesuatu.

Berdasarkan hasil yang diperoleh dapat disimpulkan bahwa kemampuan membaca permulaan yang diberikan metode pembelajaran mind map terhadap anak yang memiliki gaya kognitif field independent lebih tinggi daripada diberikan metode pembelajaran mind map yang memiliki gaya kognitif field dependent.

Nilai kemampuan membaca permulaan yang diberikan metode pembelajaran bercerita yang memiliki gaya kognitif field independent akan lebih rendah daripada nilai kemampuan membaca permulaan yang diberikan metode pembelajaran bercerita yang memiliki gaya kognitif field dependent.

Berdasarkan hasil pengolahan data terdapat perbedaan kemampuan membaca permulaan yang diberikan metode pembelajaran bercerita yang memiliki gaya kognitif field independent dengan anak diberikan metode pembelajaran bercerita yang memiliki kemampuan field dependent dipengaruhi oleh motivasi eksternal yang berasal dari orang lain, bila menggunakan metode pembelajaran bercerita guru memberikan motivasi, arahan, yang membuat kegiatan pembelajaran terarah dan terstruktur. Sehingga anak yang memiliki gaya field dependent merasa nyaman dalam belajar bahkan dengan kegiatan tersebut akan membuat anak menjadi mandiri.

Hal ini sesuai dengan pendapat Dhieni bahwa kemampuan membaca dipengaruhi oleh faktor motivasi, lingkungan keluarga dan bahan bacaan (Nurbiana, 2001). Hal inilah sesuai dengan metode pembelajaran bercerita yang utama adanya peran lingkungan, kegiatan pembelajaran tersusun, dan pemberian tugas kepada anak yang memiliki gaya kognitif field dependent cocok dan sesuai dengan karateristik kemampuan kognitif tiap anak.

Kemudian metode pembelajaran bercerita yang memiliki gaya kognitif field independent memiliki hasil yang lebih rendah karena proses pembelajaran membaca sudah tersusun dibuat oleh guru, apabila anak yang telah memiliki motivasi dari dalam maka kemampuan membaca akan kurang kreatif, terbatas, dan tidak memiliki kemampuan yang dibandingkan dengan yang lain.

Selanjutnya, sesi bercerita guru selalu berusaha mengaktifkan respon anak dan partisipasi anak dengan jalan memberikan kesempatan bagi mereka untuk mengulang kembali beberapa ekspresi dan bertanya jawab mengenai isi cerita. Anak mampu memberikan respons positif sebagai timbal balik atas pertanyaan atau sikap guru dan mereproduksi informasi yang telah mereka peroleh sebagai bentuk pemahaman dari hasil mendengarkan cerita (Abad \& Usia, 2014). 
Karena gaya kognitif field dependent anak menunggu arahan dari guru belum adanya inisatif dalam diri, harus adanya motivasi dari orang lain. Dengan menggunakan metode bercerita guru aktif dalam kegiatan pembelajaran memberikan cerita, memberikan arahan, dalam kegiatan pembelajaran sehingga menjadi terarah dan terstruktur. Jika anak dengan field independent anak merasa terbatasi, kurang kreatif, sehingga tidak dapat memotivasi dirinya sendiri.

Berdasarkan hasil yang diperoleh dapat disimpulkan kemampuan membaca permulaan yang diberikan metode pembelajaran bercerita yang memiliki gaya kognitif field independent lebih rendah dari metode pembelajaran bercerita yang memiliki gaya kognitif field dependent.

\section{KESIMPULAN}

Metode pembelajaran dapat mempengaruhi kemampuan membaca permulaan anak. Gaya kognitif juga dapat mempengaruhi kemampuan membaca permulaan anak. Dalam penelitian ini terdapat interaksi yang signifikan antara penerapan metode pembelajaran dan gaya kognitif dalam menentukan kemampuan membaca permulaan anak. Terdapat pula perbedaan yang signifikan kemampuan membaca permulaan anak yang diberikan metode pembelajaran Mind Map bagi anak dengan kemampuan gaya kognitif field independent dengan anak yang diberikan metode pembelajaran bercerita.

Terdapat perbedaan yang signifikan terhadap kemampuan membaca permulaan yang diberikan metode pembelajaran Mind Map bagi anak gaya kognitif field dependent dengan anak yang diberikan metode pembelajaran bercerita.

Dalam penelitian ini terdapat perbedaan yang signifikan kemampuan membaca permulaan yang diberikan metode pembelajaran Mind Map bagi anak gaya kognitif field independent dengan anak gaya kognitif field dependent. Selanjutnya, terdapat perbedaan yang signifikan kemampuan membaca permulaan yang diberikan metode pembelajaran bercerita bagi anak yang memiliki gaya kognitif field independent dengan anak yang memiliki gaya field dependent.

\section{UCAPAN TERIMA KASIH}

Terima kasih saya ucapkan kepada dosen pembimbing yang telah membina, memotivasi serta membantu dalam pembuatan jurnal dan menyelesaikan tugas akhir.

\section{DAFTAR PUSTAKA}

N. W. A. N., . D. N. W., \& Nice Maylani Asril, S. P. ,M. P. . (2014). Penerapan Metode Mind Map Berbantuan Media Gambar Untuk Meningkatkan Perkembangan Bahasa Anak Kelompok B2. Jurnal Pendidikan Anak Usia Dini Undiksha, 2(1). Retrieved from https://ejournal.undiksha.ac.id/index.p hp/JJPAUD/article/view/3519/2838

Abad, K., \& Usia, A. (2014). Metode Picture Mapping Dalam Kegiatan Storytelling: Cara Untuk Mengembangkan. 1-10

Babayiğit, S. (2015). The relations between word reading, oral language, and reading comprehension in children who speak English as a first (L1) and second language (L2): a multigroup structural analysis. Reading and Writing, 28(4), 527-544. https://doi.org/10.1007/s11145-0149536-x

Bond, M. A., \& Wasik, B. (2001). Beyond the Pages of a Book: Interactive Book Reading and Language Development in Preschool Classrooms. Journal of Educational Psychology, 93(2), 243250. https://doi.org/10.1037//0022O663.93.2.243 
Čoban, S., \& Tokatli, E. S. (2017). The effect of mind mapping technique on students' achievements in music lesson and on their attitudes towards the mind mapping technique. Egitim ve Bilim, 42(190), 423-435. https://doi.org/10.15390/EB.2017.685 6

Cools, E. (2009). A reflection on the future of the cognitive style field: a proposed research agenda. . . Vlerick Leuven Gent Management School, Belgium, Vol 5, No

Dhindsa, H. S., Makarimi-Kasim, \& Anderson, O. R. (2011). Constructivist-Visual Mind Map Teaching Approach and the Quality of Students' Cognitive Structures. Journal of Science Education and Technology, 20(2), 186-200. https://doi.org/10.1007/s10956-0109245-4

Djaali, \& Muljono, P. (2008). Pengukuran Dalam Bidang Pendidikan. Jakarta: Grasindo

Geown, S. M. (2015). Synthetic Phonics Vs. An Eclectic Approach To Reading Instruction: Implications For The Skills Predicting Early Reading Acquisition And Development. The Psicology of Education Review, Volume 39,.

Handini, M. (2012). Metodologi Penelitian untuk Pemula. Jakarta: FIP Press

Isbell, R., Sobol, J., Lindauer, L., \& Lowrance, A. (2004). The Effects of Storytelling and Story Reading on the Oral Language Complexity and Story Comprehension of Young Children. Early Childhood Education Journal, 32(3), $157-$ 163.https://doi.org/10.1023/b:ecej.000 0048967.94189.a3

Jones, B. D., Ruff, C., Snyder, J., Petrich, B., \& Koonce, C. (2012). The Effects of Mind Mapping Activities on Students' Motivation. International Journal for the Scholarship of Teaching and Learning, 6(1). https://doi.org/10.20429/ijsotl.2012.0 60105

Kebudayaan, K. P. dan. (2012). Dokumen kurikulum 2013.

Moeslichtoen. (2004). Metode Pengajaran Di Taman Kanak-Kanak. Jakarta: Rineka Cipta.

Mwoma, T. (2017). Children's reading ability in early primaryschooling. volume 27(Issue in educational research).

Nurbiana, D. (2001). Metode Pengembangan Bahasa. Jakarta: Pusat Penerbitan Universitas Terbuka

OECD. (2016). Country note - results from PISA 2015: Indonesia. Oecd, 1-8. Retrieved from https://www.oecd.org/pisa/PISA2015-Indonesia.pdf

Olivia, F. (2008). Gembira Belajar dengan Mind Mapping. Jakarta: Elex Media Komputindo.

Pungello, E. P., Iruka, I. U., Dotterer, A. M., Mills-Koonce, R., \& Reznick, J. S. (2009). The Effects of Socioeconomic Status, Race, and Parenting on Language Development in Early Childhood. Developmental Psychology, 45(2), 544-557. https://doi.org/10.1037/a0013917

Roopnarine, J. L., \& E, J. J. (2011). Pendidikan Anak Usia Dini Dalam Berbagai Pendekatan Edisi Kelima. Jakarta: Kencana Prenada Media Group.

Santrock, J. W. (2008a). ). Educational Psychology Third Edition. New York: Mc Graw Hill.

Smith, M. K. (2009). Teori Pembelajaran dan Pengajaran Dilengkapi Dengan Manajemen Ingatan Emosional dan Cara Cepat Memperbaiki Daya Ingat. Jogjakarta: Mirza Media Pustaka.

Tjoe, J. L. (2013). Meningkatkan kemampuan membaca permulaan melalui pemanfaatan multimedia. Jurnal Pendidikan anak usia dini. volume $7 e$.

Woolfolk, A. (2006). Educational Psychologi. New Delhi: Dorling Kindersley India, Pvt, LTd.

Yasa, A., \& Dkk. (2013). Pengaruh Pendidikan Matematika Realistik Dan Gaya Kognitif Terhadap Prestasi Belajar Matematika Siswa 